第 7 表

\begin{tabular}{|c|c|c|c|c|c|c|c|c|c|c|c|c|c|}
\hline \multirow{2}{*}{$\begin{array}{l}\text { 年 } \\
\text { 度 } \\
\text { 別 }\end{array}$} & \multirow{2}{*}{ 年間出鉱量 $(\mathrm{t})$} & \multicolumn{3}{|c|}{ 平 均 } & \multicolumn{2}{|c|}{ 1人1カ月当出鉱量 } & \multirow{2}{*}{$\begin{array}{l}\text { 年 } \\
\text { 度 } \\
\text { 別 }\end{array}$} & \multirow{2}{*}{ 年間出鉱量 $(\mathbf{t})$} & \multirow{2}{*}{$\begin{array}{c}\text { 平 } \\
\mathrm{Pb}(\%) \\
\mathrm{Au}(\mathrm{g} / \mathrm{t})\end{array}$} & \multirow{2}{*}{$\begin{array}{l}\text { 均 品 } \\
\begin{array}{l}\mathrm{Zn}(\%) \\
\mathrm{Ag}(\mathrm{g} / \mathrm{t})\end{array}\end{array}$} & \multirow{2}{*}{$\begin{array}{c}\text { 位 } \\
\mathrm{S}(\%) \\
\mathrm{SiO}_{2}(\%)\end{array}$} & \multicolumn{2}{|c|}{1 人 1 力月当出釷量 } \\
\hline & & $\mathrm{pb}$ & $\mathrm{Zn}$ & $\mathrm{S}$ & 坑内 $(t$ & 全山( $t)$ & & & & & & 坑内 $(t)$ & )全山( $t$ ) \\
\hline $\begin{array}{l}32 \\
33 \\
34 \\
35 \\
36 \\
37 \\
38 \\
39\end{array}$ & $\begin{array}{l}16,391 \\
16,674 \\
10,503 \\
43,642 \\
53,163 \\
57,254 \\
67,993 \\
91,772\end{array}$ & $\begin{array}{l}4.37 \\
4.13 \\
3.16 \\
3.40 \\
2.87 \\
2.94 \\
2.46 \\
1.99\end{array}$ & $\begin{array}{l}4.89 \\
4.77 \\
3.50 \\
3.75 \\
3.45 \\
3.93 \\
4.41 \\
3.32\end{array}$ & $\begin{array}{l}13.94 \\
13.79 \\
14.94 \\
13.95 \\
13.81 \\
12.84 \\
11.89 \\
14.02\end{array}$ & $\begin{array}{l}54.8 \\
46.6 \\
95.5 \\
98.1 \\
68.3 \\
58.1 \\
59.7 \\
65.6\end{array}$ & $\begin{array}{l}40.0 \\
36.8 \\
31.8 \\
39.7 \\
37.9 \\
35.8 \\
38.1 \\
44.8\end{array}$ & $\begin{array}{c}40 \\
41 \\
\text { 諳 } \\
\text { 平均 }\end{array}$ & \begin{tabular}{|lc}
$\mathrm{P} . \mathrm{b} \cdot \mathrm{Zn}$ & 95,098 \\
$\mathrm{SiO}_{2}$ & $6,090.336$ \\
$\mathrm{pb} \mathrm{Zn}$ & 93,328 \\
$\mathrm{SiO}_{2}$ & $8,879.327$ \\
$\mathrm{pb} \mathrm{Zn}$ & 545,817 \\
$\mathrm{SiO}_{2}$ & $14,969.663$ \\
$\mathrm{pbZn}^{2}$ & 54,582 \\
$\mathrm{SiO}_{2}$ & $7,484.832$
\end{tabular} & $\begin{array}{l}1.90 \\
11.8 \\
2.56 \\
6.5 \\
2.59 \\
8.7 \\
2.59 \\
8.7\end{array}$ & $\begin{array}{l}3.48 \\
7.58 \\
3.99 \\
6.28 \\
3.81 \\
6.81 \\
3.81 \\
6.81\end{array}$ & $\begin{array}{l}14.04 \\
87.30 \\
11.46 \\
85.41 \\
13.16 \\
86.18 \\
13.16 \\
86.18\end{array}$ & $\begin{array}{l}48.6 \\
49.1 \\
57.8 \\
63.9\end{array}$ & $\begin{array}{l}33.8 \\
35.3 \\
37.3 \\
41.3\end{array}$ \\
\hline
\end{tabular}

細倉鉱山

\title{
Hosokura Mine
}

\section{1. 緒言}

細倉鉱業所は宮城県栗原郡にあり，東北本線石越駅よ り宮城中央交通社線にて約40分で達する。仙台平野に連 なる山間の平坦な地にあり，通洞坑口は海抜 $106 \mathrm{~m}$ であ る。

約1100年前に発見され，江戸時代は仙台藩により採掘 された。明治以降民有となり，昭和 9 年当社の前身たる 三菱鉱業株式会社の経営に移り, 戦後太平鉱業株式会社 と改称の時期を経て，昭和 27 年三菱金属鉱業株式会社と 改称した当社の経営により現在に至る。

昭和 42 年 3 月の現状を第 $1 \sim 4$ 表に示す。
第 1 表 粗鉱量と出鉱品位

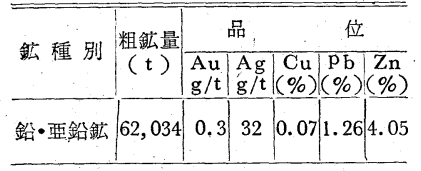

第 2 表 従 業員 (鉣山関係)

\begin{tabular}{|c|c|c|c|}
\hline & 坑内 & 坑外 & 計 \\
\hline 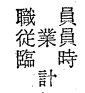 & $\begin{array}{r}46 \\
632 \\
678\end{array}$ & $\begin{array}{r}102 \\
521 \\
23 \\
646\end{array}$ & $\begin{array}{r}148 \\
1,153 \\
23 \\
1,324\end{array}$ \\
\hline
\end{tabular}

第 3 表 採掘法別出鉱量扎よび切羽数

\begin{tabular}{|c|c|c|c|}
\hline 採. 掘 法の種 類 & 出鉱量 $(\mathrm{t})$ & 出鉱比率 & 切羽数 \\
\hline 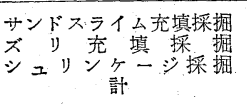 & $\begin{array}{r}8,911 \\
1,568 \\
40,869 \\
51,348\end{array}$ & $\begin{array}{r}17.35 \\
3.06 \\
79.59 \\
100\end{array}$ & $\begin{array}{l}16 \\
11 \\
69 \\
96\end{array}$ \\
\hline
\end{tabular}

第 4 表 開採鉱出鈗量执よび試錐延長

\begin{tabular}{|c|c|c|c|c|c|}
\hline \multirow{2}{*}{$\begin{array}{c}\text { 試 錐延長 } \\
(\mathrm{m})\end{array}$} & \multirow{2}{*}{$\begin{array}{c}\text { 探 鉱延長 } \\
(\mathrm{m})^{2}\end{array}$} & 出 & 鉱 & \multicolumn{2}{|c|}{ 量 ( $\mathrm{t}$ ) } \\
\hline & & 開 坑 & 採 & 鉱 & 計 \\
\hline 668.89 & $1,916.25$ & 10,689 & & 348 & 62,034 \\
\hline
\end{tabular}

\section{2. 地質・鉱 床}

2.1 地質 (第 1 図参照)

\section{正会員井口正澄* Masazumi INOKUCHI}

細倉鉱山付近の地質は，第三紀中新世の緑色凝死岩類 と, 鮮新世の石英安山岩質凝灰岩, 凝灰岩質頁岩よりな り, これらが先第三紀の基盤を不整合に覆つて広く分布 している。これらの地質の上に第四紀の新期火山岩類, 段丘堆積物がみられる。

本地域に扔ける層序は, 中新世を下部より細倉層, 中 山層, 宮口層, 細越層に区分し, 一方鮮新世を文字層, 六角層に区分している。稼行対象となる鉱体の胚胎層準 は，主として細倉層である。

細倉層㵊下部凝灰岩類, 流紋岩㥞岩石, 下部凝灰岩 類, 安山岩拉よび变朽安山岩類, 上部凝灰岩類に分類で きる。

\section{$2 \cdot 2$ 鉱 床}

鉱床は, 前記凝灰岩類, 変朽安山岩類, 流紋岩様岩 石, 後期変朽安山岩類中に形成された熱水性の鉛・亜鉛 鉱脈である。既知鉱脈は，百有余条におよび，一般に延、 長は200 600mであるが, $2 \mathrm{~km}$ におよぶものもある。 平均脈幅は $1.5 \mathrm{~m}$ 前後, 傾斜注70 80 0 のものが多い。

鈗石鈗物は, 閃亜鉛鉱, 方鉛鉱, 黄鉄鉱を主とし, 局 部的江少量の白鉄鉣, 黄銅鉱, 赤鉄鉱, 輝安鉱, 輝銀 鉱，濃紅銀鉱などを伴つている。

鉱床は, 東西約 $6 \mathrm{~km}$, 南北約 $4 \mathrm{~km}$ の地域に胚胎し ており，41年 12 月末埋蔵鉱量は 1,050 万 $\mathrm{t}$, 品位は $\mathrm{Pb}$ $1.61 \%$, Zn $4.74 \%$ である。

\section{3. 採 掘法}

\section{$3 \cdot 1$ 採掘法の変遷およびその採用の理由}

旧時代においては，高品位で鉛に富み，しかも母岩， 鉱脈ともに堅硬な部分を抜掘式上向階段法によつて採掘 していた。その後採掘対象が, 低品位で, 条件の悪い脈 に移行していつたが, もつぱらシニリンケージ法によつ 


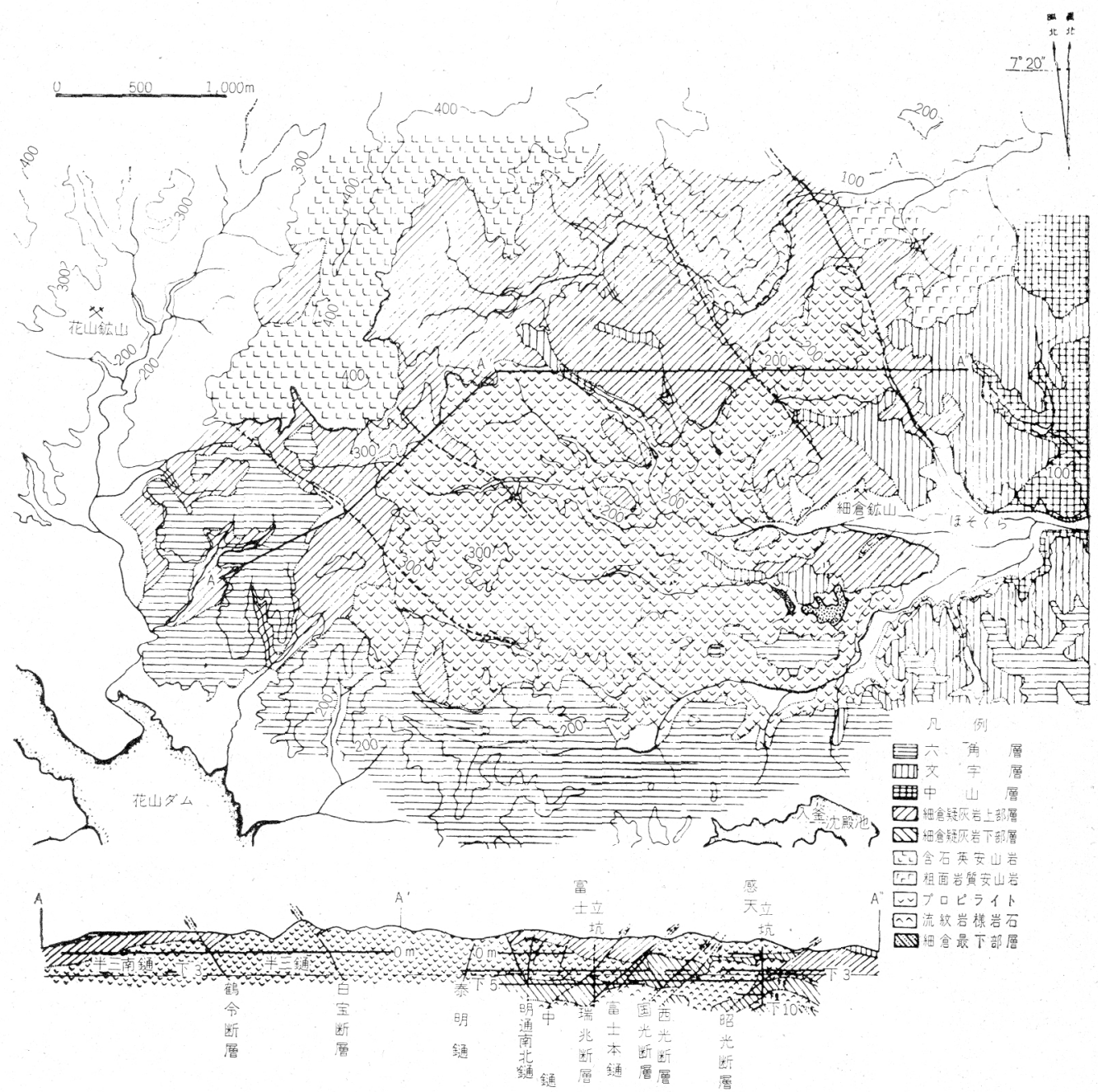

第1図 細倉鉣山周辺地質図招よび地質断面図

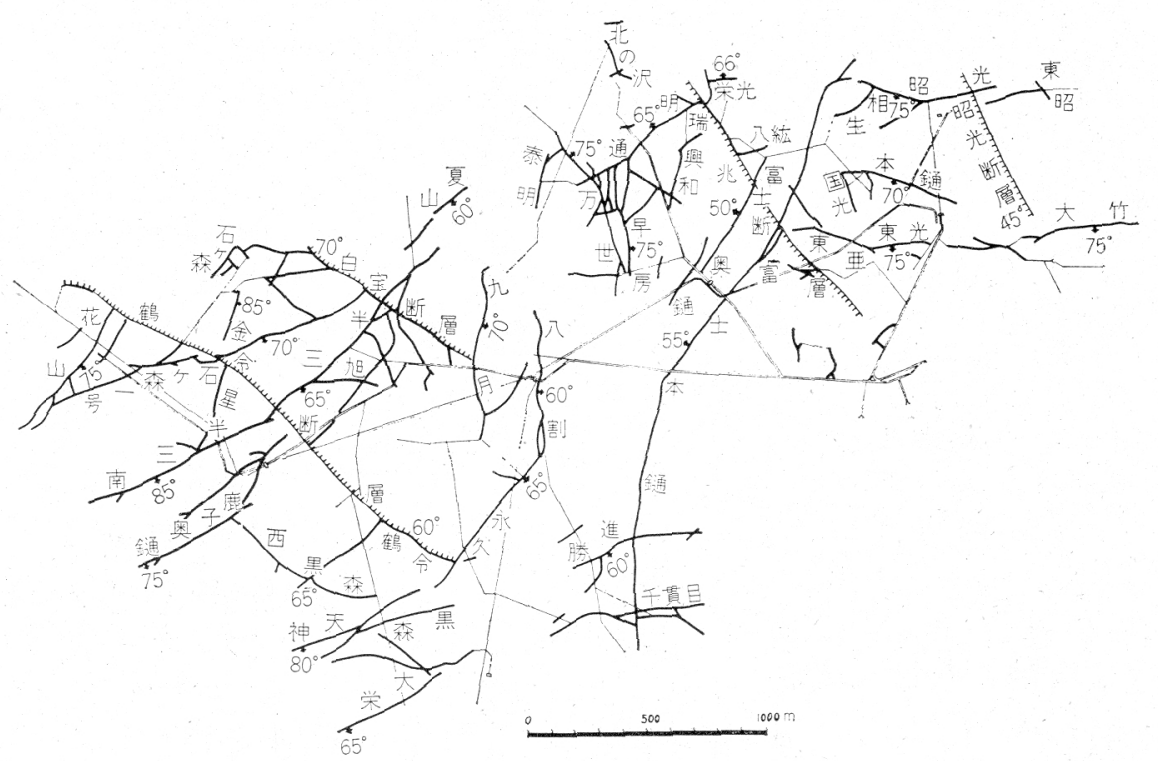

第 2 図細倉鉣山鉣脈分布図 
て採掘を行なつてきた。

シニリンケージ法は, 長く採掘法の骨幹をなしていた が，その採用にあたつて考慮された諸条件を列挙すれば つぎのと晾りである。

（1）鉱脈の傾斜が，平均 $70^{\circ}$ で概して急傾斜であ る。

（2）脈幅が比較的狭いため鉱石の抽出が完全に近 w。

（3）鉱脈の形状が割合に規則正しいので，破砕され た鉱石が下盤の上に残ることは少ない。

（4）鉱石は概して堅硬であり，採掘中に天盤が落ち るようなことはない。

（5）採掘切羽として選定された鉱画内における品位 の変化は，割合に少ない。

（6）採掘中あるいは採掘終了後鉱石引下げの間， 上,下盤の崩落は比較的少ない。

（7）鉱石の性質は，粘土を含み多少抜けにくい脈む あるが，常時鉣石を動かすことによりこれを防ぐことが できる。

しかしながら，つぎの理由から，漸次充填採掘に移行 しており, 現在ではシニリンケージ法と充填採掘法を併 用している。

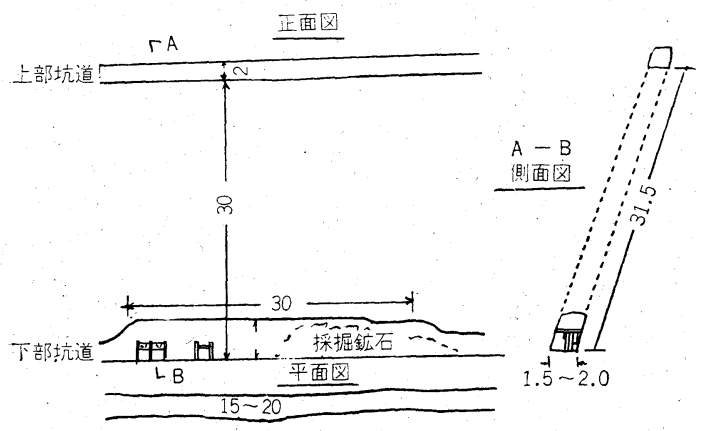

(a) 3 号欠の段階

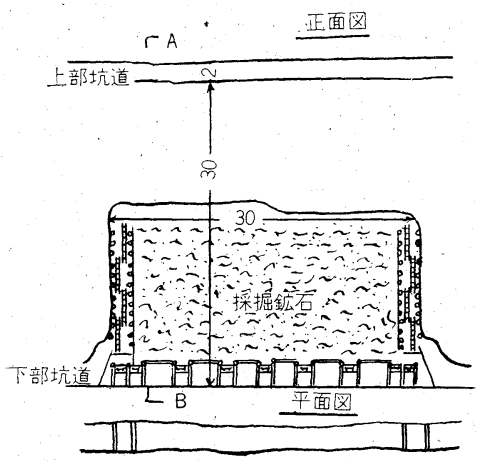

(b) 採掘中の状態

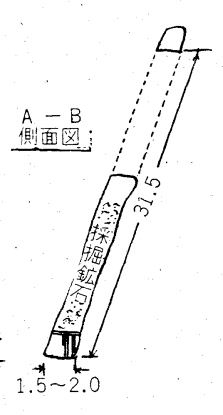

（1）採掘区域が深部に移行するに従い，岩盤条件が 悪化している。

（2）採掘実収率の向上，およびズリ混入防止による 採掘品位の向上を計る。

（3）採掘切羽の集約化を行ない，生産工程の上昇上 保安の確保を計る。

\section{$3 \cdot 2$ 現在の採掘法の種類}

シュリンケージ法を主力として抢り，採掘出鉱の約70 \%を占め, その他は充填採掘法によつている。充買材の 大部分は，サンドスライムであるが，一部開坑ズリ処理 のため生ズリも使用している。

\section{3 主たる採掘法の説明}

3.3.1 シュリンケージ採掘法 (第 3 図参照): 第 3 図 は，シニリンケージ採掘法の一般的手順を示す。すなわ ち(a)は 3 号欠の段階を示し, 採掘鉱画の下底坑道にお いて, ストーパーにより 3 スライスの採掘を行ない, 破 砕鉱をローデングした後, 採掘棚扔よび鉣石漏斗の取付 を開始する。

（b）は完成した採掘棚（のしだな）を足場として上向 きに採掘を開始するが，最初は棚をいためないように小 発破を行ない，その破砕鉣を棚の上に拉げてまた小発破 を行なうというように, 慎重に採掘を進めて行く。

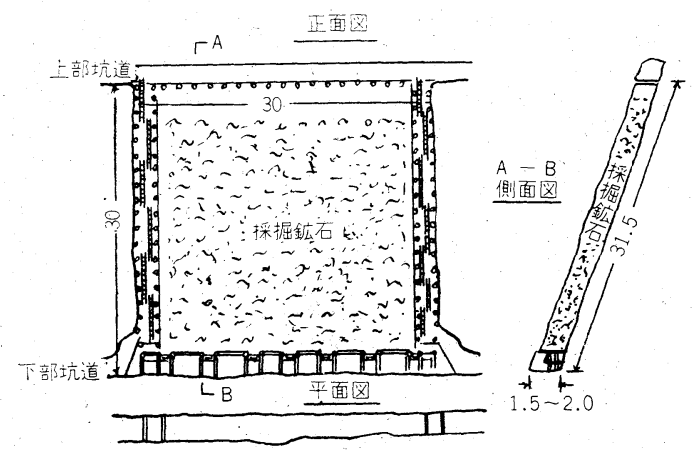

（c）採掘完了の状態

第３図 シニリンヶージ法による採掘順序 
1スライスを終つてつぎのスライスに移るまでに，天 盤と足場鉱石との距離が $2 \mathrm{~m}$ になるように破研鉱を漏斗 から引き抜く。以下逐次同様な方法を繰返して上向に採 掘して行く。また切羽の上昇に応じて両側の人道も伸ば 乙て行く。

（c） は採掘の完了した直後の状 態を示す。すなわち，この場合は所 定の鉱画を完全に採掘し，上部坑道 の踏前には二重棚を打込んだところ である。この時採掘した鉱石量の 40 〜 50\%は貯鉱になつている。

(d) は(c) と同様採掘完了直後 の状態であるが，上部坑道の踏前竜 頭を必要とした状態を示す。

\section{$3 \cdot 3 \cdot 2$ サンドスライム充填採掘} 法（第 4 図参照）：第 4 図は当所に おけるサンドスライム充垻採掘法を 示す。採掘鉱画長さ $34 \mathrm{~m}$ の中心に 4 $\mathrm{m}$ の掘上りを上部坑道に 貫 通させ る。掘上りの両側 $15 \mathrm{~m}$ をストパに より 3 スライス採掘しシュリンケ 一ジ法と同様に採掘棚の取付を行な ら。漏斗は人道両側に設け，採掘棚 の上には莚を敷きならべ，漏斗の仕 切板をはり，水拔き用マウストラッ プを取付けて後初充填を行なう。

充墤は天盤との高さが $2 \mathrm{~m}$ 程度に なるように調整する。最初の発破は 本棚の損傷を防ぐため，できる限り 慎重に軽く発破を行なら。発破後 は，スラッシャにより破研鉣をス卜 一パ使用可能となるよう搔きなら す。2 スライス終了後破砕鉱のスラ ッシングを行ない, "っぎに充填段
取，充填を行なう。以後人道両側のスパンを交互にスデ イス採掘，スラッシング，充塡を繰返す。

スラッシャは上部坑道に設置して，遠隔操作により運 転する。

充垻系統は第 5,6 図に示すものである。
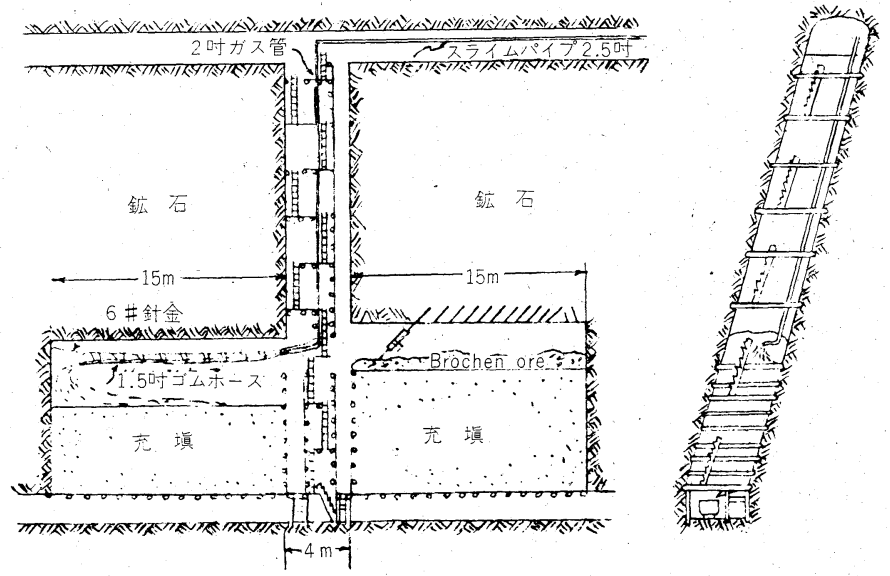

第 4 図 サンドスライム充填採掘切羽図

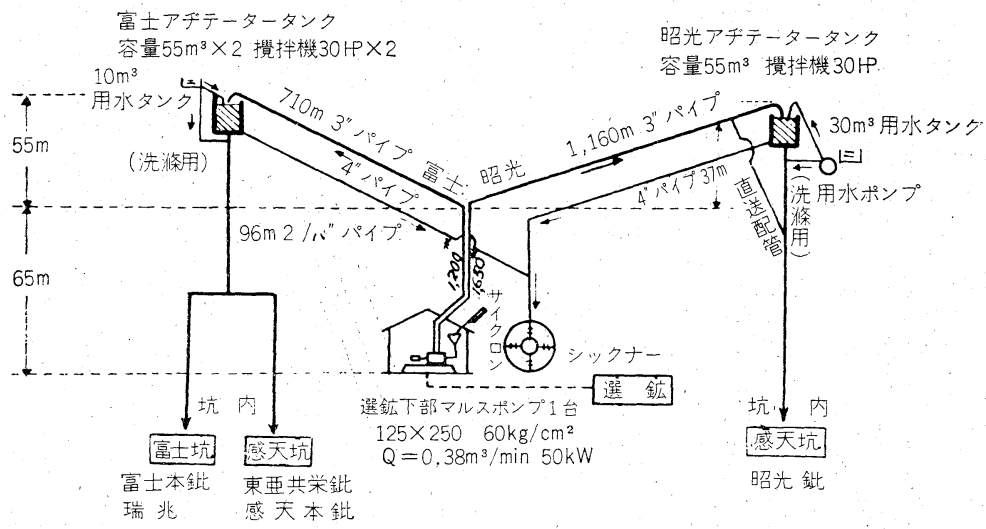

第 5 図 富士, 感天, 昭光サンドスライム充壃系統

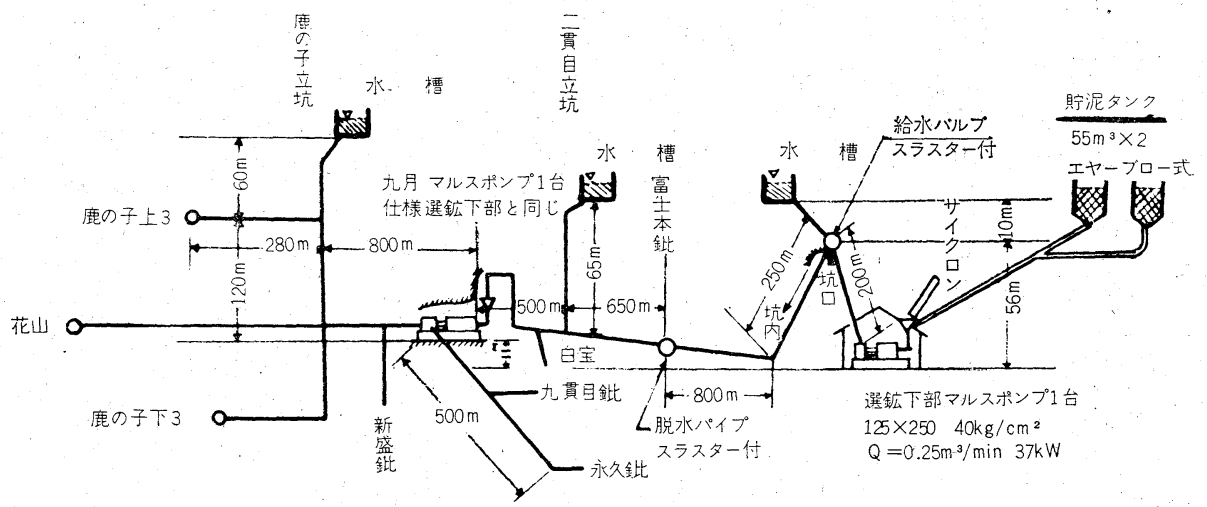

第6図 二貫目，鹿の子サンドスライム充填系統 
井口：細 倉 鉱山

第 5 表 採掘法別工程原単位扣よび採掘費

（40年4月～40年 9 月実績）

\begin{tabular}{|c|c|c|c|c|c|c|c|c|c|c|c|c|c|c|c|}
\hline \multirow[b]{2}{*}{ 採 } & \multirow{2}{*}{ 掘 } & \multirow[b]{2}{*}{ 法 } & \multirow[b]{2}{*}{ 別 } & \multirow{2}{*}{$\begin{array}{c}\text { 採 掘 量 } \\
\mathrm{t} / \text { 月 }\end{array}$} & \multirow{2}{*}{$\begin{array}{l}\text { 充 填量 } \\
\mathrm{m}^{3} / \text { 月 }\end{array}$} & \multirow{2}{*}{ 数 } & \multicolumn{2}{|l|}{ 原 } & 単 & \multicolumn{2}{|c|}{ 位 } & \multicolumn{2}{|c|}{ 採 } & 鉣 & 費 \\
\hline & & & & & & & 工 数 I/t & $\begin{array}{l}\text { 爆 薬 } \\
\end{array}$ & $\begin{array}{l}\text { 㻠 木 } \\
\mathrm{m}^{3} / \mathrm{t}\end{array}$ & $\begin{array}{c}\text { 鋼 材 } \\
\mathrm{kg} / \mathrm{t}\end{array}$ & $\begin{array}{l}\text { 電 力 } \\
\mathrm{kWh} / \mathrm{t}\end{array}$ & 人 件 & 物 品 & その他 & 計 \\
\hline \multicolumn{4}{|c|}{ 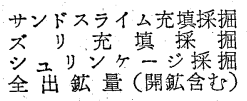 } & $\begin{array}{r}10,624 \\
2,198 \\
29,758 \\
56,420\end{array}$ & $\begin{array}{r}6,313 \\
867 \\
-\end{array}$ & $\begin{array}{r}1,296 \\
459 \\
2,772 \\
-\end{array}$ & $\begin{array}{c}0.12 \\
0.21 \\
0.09 \\
\text { 坑内夫 } 0.274\end{array}$ & $\begin{array}{l}0.34 \\
0.32 \\
0.36 \\
0.683\end{array}$ & $\overline{\bar{z}}$ & $\overline{\bar{z}}$ & $\frac{\bar{z}}{27.6}$ & $\overline{\bar{z}}$ & $\frac{\bar{z}}{393}$ & $\overline{\bar{E}}$ & $\frac{\bar{Z}}{1, \overline{868}}$ \\
\hline
\end{tabular}

（42年3月実 績）

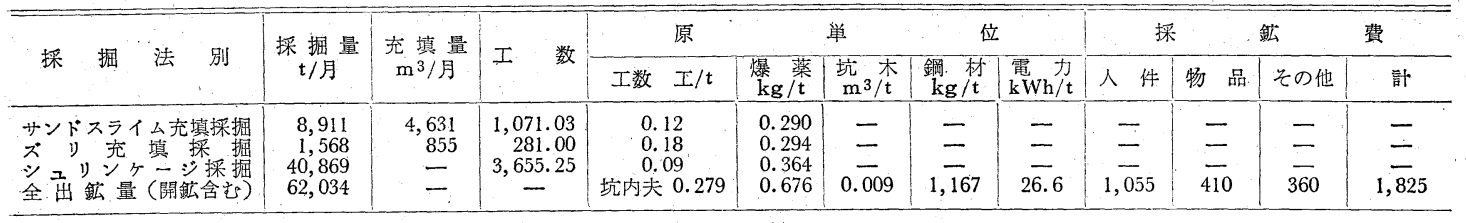

富士，感天，昭光地区は，選鉣からアジテータータン クに送泥し，タンクからは自然ヘッドにより送泥する。 この場合の送泥量は, 毎時 $60 \mathrm{~m}^{3}$ 程度である。

なお，昭光地区へは，毎分 $0.38 \mathrm{~m}^{3}$.で選鉣より直接送 泥を行なつている。

二貫目，鹿の子地区は，選鉱から坑内中継ボンプを経 て切羽に送泥する。この場合の送泥量は，毎分 $0.25 \mathrm{~m}^{3}$ である。

\section{4. 運搬（主要系統，設備等）}

\section{$4 \cdot 1$ 鉱石}

鉱床賦存範囲が広大なことと，近年における著しい操 業規模の膨張のため, 主要運搬系統の合理化に主力を注 いできた。過去10年間の合理化工事のらち，主なものは つぎのとおりである。

（1）中央立坑を廃止し，242mの斜坑を開さくして，

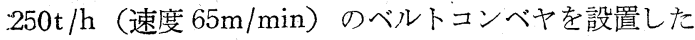
(昭和 32 年)。

（2）富士立坑に3t スキップを設置した(昭和32年)。
(3) 下 3 番坑に $3,800 \mathrm{~m}$ の主要運搬坑道を開さく し，富士立玾スキップにて集中巻上げを行なつた（昭和 35年)。

（4）増産計画により，下5 番坑〜通洞間に $768 \mathrm{~m} の$ 斜坑を開さく, $250 \mathrm{t} / \mathrm{h}$ のベルトコンベヤを設置した（昭 和38年)。

（5）主要鉱脈である昭光銿などの下部開発に伴い, 昭光, 感天, 富士各立坑を下部に延長した。またこれら の立坑運搬量軽減のため, 富士, 昭光各立坑間を連絡す る延長 $1,200 \mathrm{~m}$ の主要運搬坑道を開さくし, 併せて富士 立坑下11番坑に破砕設備を設けた（昭和41年）。

（6）今後の増産に対処するため, 斜坑コンベヤを増 速して $130 \mathrm{~m} / \mathrm{min}$ とした（昭和 41 年）。

現状の運搬系統は第11表に示すように，各坑とも下 3 番坑以上の鉱石は5 6 $\mathrm{t}$ トロリ一電車で牽引儿, 直接富 土坑貯鈗舎に送り，下 3 番坑以下の鉣石は，各立坑で巻 上げて各坑貯鉱舎に集鉱した後, 富士坑貯鉱舎に送鉱 し，クラッシャで破砕した後，ベルトコンベヤで選鉱場 に送つている。昭和 41 年下 10 番坑主要運搬坑道が完成し

第6 表 主 要 運 搬 設 備

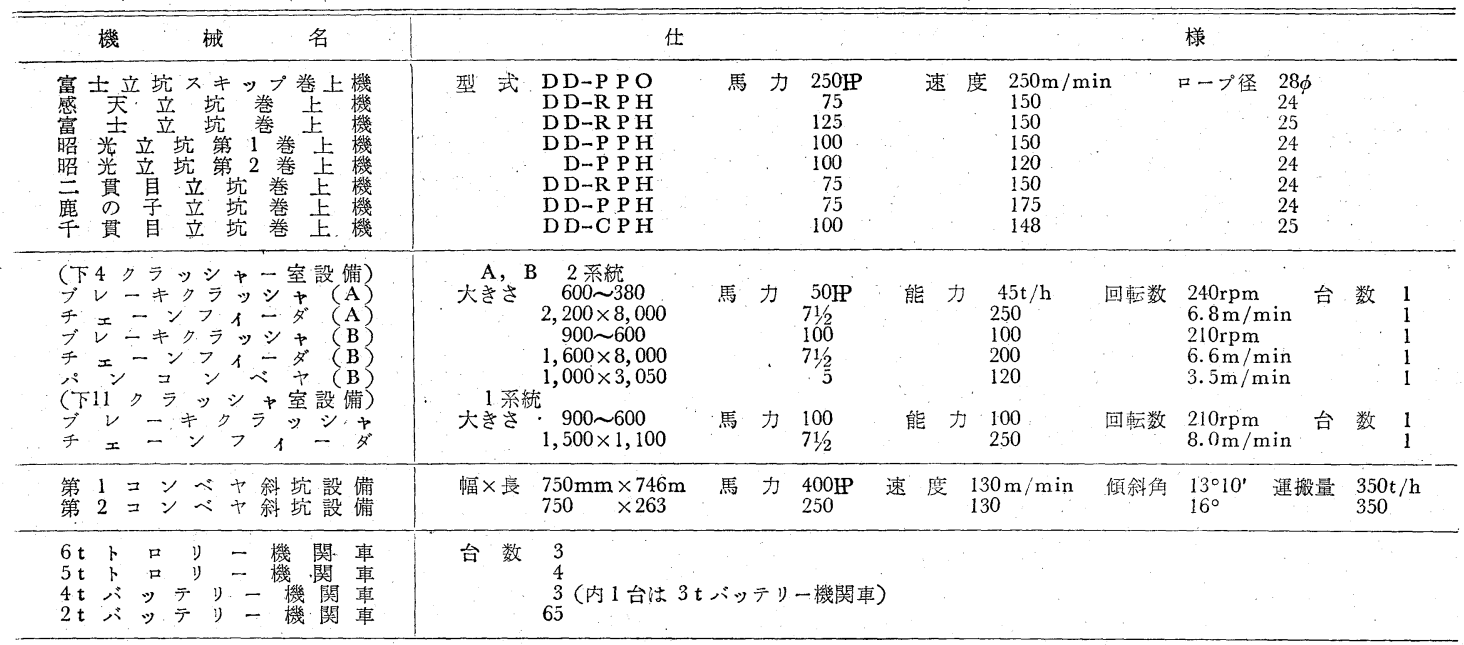




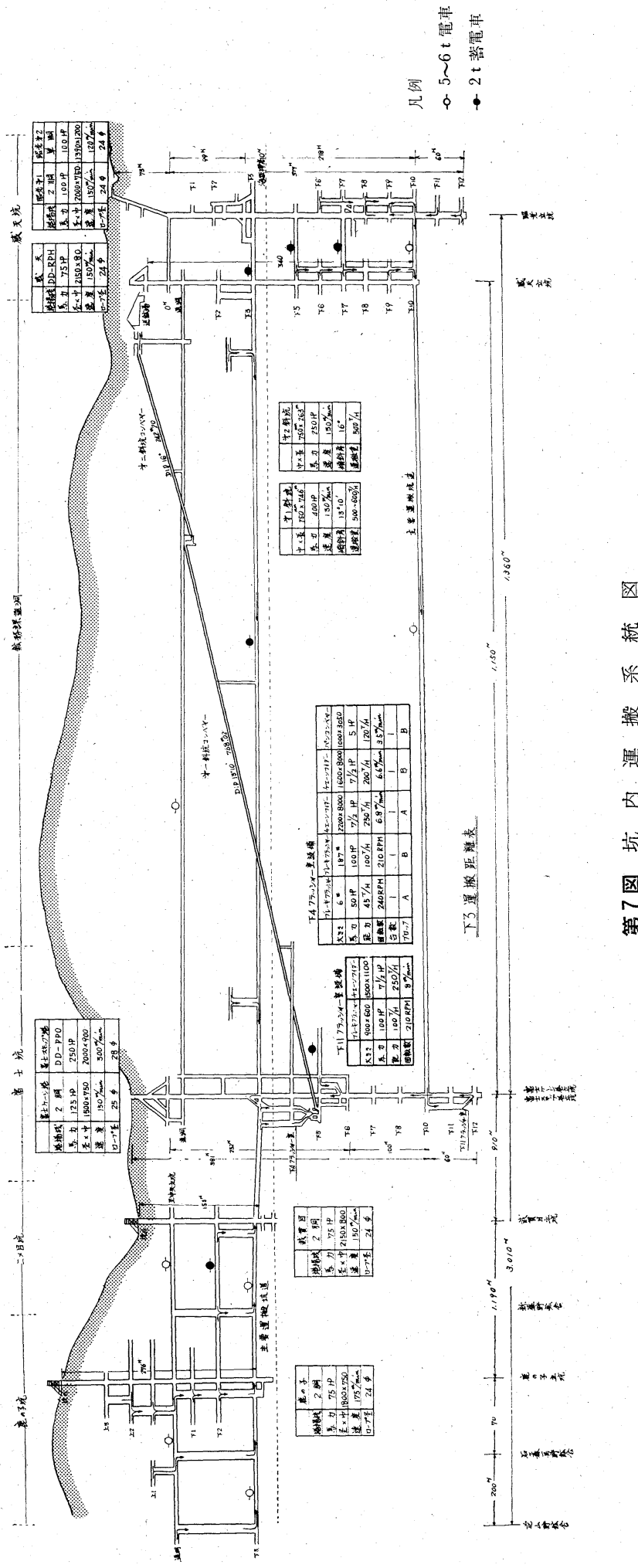

たため, 感天坑および富士坑の下 3 番坑以 下の鉱石は，下10番坑を経て，富士立坑下 10 11番坑間の主要貯鉱舎に送鉱するよう に変更した。このため感天および富士坑の 下部探鉱と増産が可能となつた。

運搬系統の主な設備は第 6 表に示寸とお である。

\section{$4 \cdot 2$ ズリ}

開坑ズリの処理は，坑内でズリ充填採掘， 切羽に利用し，かつジリンケージ採掘跡 に充填する。

上記以外は，立坑により巻上げ坑外に堆 積している。

\section{$4 \cdot 3$ 人員}

稼行地域が広いため，一部を除いて入出 坑は人車により各坑坑内事務所にいたり， 立坑ケージで各坑道に昇降する。

\section{4 材料}

坑木類など諸材料は，通洞坑より材料運 搬電車により各坑主要集積場に運搬し，立 坑により各坑道に配給される。

\section{5. 通気, 排水, 照明, 保安, その他}

\section{$5 \cdot 1$ 通気}

各坑それぞれ数力所の入排気坑があるた め, 一部を除いては充分な通気量を得るの で，自然通気を主とするが，感天坑昭光地 区の鉱石酸化熱に上る高温個所には, 通気 専用掘上り 2 本を坑外に貫通させ， $100 \mathrm{~kW}$ および $40 \mathrm{~kW} の 2$ 台のターボフアンによる 強制通気を行ない，切羽温度を $26^{\circ} \mathrm{C}$ 前後に 下げている。

なお，局部的通気不良個所には，必要に 応して小型局部扇風機を用いて通気改善を 計つている。

\section{$5 \cdot 2$ 排水}

昭和 41 年に, 富士立坑下 10 番坑に $500 \mathrm{PP}$ タービンポンプ 2 台を設置して排水設備の 統合を行ない，富士，感天坑下 3 番坑以下 の坑内水はすべて富士立坑下10番坑集水 し, 通洞に直接揚水している。その他，富 士，感天坑下 3 番坑より上部の坑内水は， 富士下 3 番坑に集水して通洞坑に排水し， 鹿の子, 二貫目坑の坑内水の一部は, 二貫 目坑下 3 番坑に集水してそれぞれのポンプ により坑外に揚水している。排水量は，年 
間を通じ平均 $5 \mathrm{~m}^{3} / \mathrm{min}$ 程度であり，ボンプは常時 $500 \mathrm{P}$ を運転している。

排水設備は第 7 表のとおりである。

第 7 表 排 水. 設 備

\begin{tabular}{|c|c|c|c|c|c|c|}
\hline 設 置 場 所。 & $\begin{array}{l}\text { 実揚程 } \\
(\mathrm{m})\end{array}$ & $\begin{array}{c}\text { ポソプ容量 } \\
\mathrm{m}^{3} / \mathrm{min}\end{array}$ & 段教 & 馬力P & $\begin{array}{l}\text { 回転数 } \\
\text { rpm }\end{array}$ & 台数 \\
\hline 富士立坑(下10) & 310 & 4.0 & 7 & 500 & 1,470 & 2 \\
\hline$\Rightarrow(\geqslant)$ & 212 & 1.56 & 9 & 150 & 1,475 & I \\
\hline 士立坑(下 12 ) & 60 & 1.56 & 4 & 75 & 1,475 & 2 \\
\hline (下 3 ) & 98 & 2.00 & 5 & 100 & 1,475 & 2 \\
\hline$(11)$ & 98 & 1.56 & 6 & 100 & 1,475 & 1 \\
\hline 昭光立坑(下12) & 60 & 1.99 & 4 & 75 & 1,475 & 2 \\
\hline 三貫目立坑(下 3 ) & 153 & 1.56 & 9 & 125 & 1,475 & 2 \\
\hline
\end{tabular}

\section{$5 \cdot 2$ 照明}

坑内主要設備および坑道は, 電灯または螢光灯による 照明を行なつているほか, 一部主要採掘切羽では, 500W の投光器を使用して保安の向上を計つている。

なお作業員は，全員 G S-C 型キャップランプを使用 している。

\section{3 保安}

従来より探鉱ならびに採掘切羽の落盤災害防止に重点 をおいて，種々対策を樹立してきたが，近年運搬災害が 増加する傾向にあるため, 有資格者再教育と運搬設備の 整備に努め, この種災害の防止に努めている。

\section{6. 問題点と将来計画}

\section{$6 \cdot 1$ 問題点}

歴年, 試錐, 坑道探鉱による埋蔵鉱量の増加が顕著で あるため，原価の上昇に対しては生産性の向上をもつて 補い，現在急速なる増産過程にある。

今後, さらに生産規模の拡大とともに, 累増する埋蔵 鈗量を完全かつ能率的に回収するためには，幾多の問題 点があるが，当面鲧案中のむのはつぎのとおりである。

(1) 低品位鉱の高能率採掘法の検討

(2) シニリンケージ等無充買採掘法の安全能率化

(3) 充填採掘法の高能率化と普及

(4) 坑内作業方式の合理化

南 越

\section{Nan-etsu Mine}

正会員 吉 $\begin{gathered}\text { 田 } \\ \text { Yutaka YOSHIDA }\end{gathered}$ 寛* $^{*}$

\section{1. 緒言}

\section{位置}

当鈗業所は北緯 37 度 5 分, 東経 139 度, 海抜 $530 \mathrm{~m}$ に位

* 東邦覀銛株式会社南越鈗業所
（5）深部開発に伴い通気ならびに運搬系統の合理化

\section{$6 \cdot 2$ 将来計画}

（1）探鉱：昭光立坑, 感天立坑をさらに延長して, 当坑下部ならびに東南部の探鉱を行なうほか, 富士立坑 を中心として，南部地区の探鉱を計画している。

(2) 技術の改善：前記のごとく埋蔵鉱量は逐年増加 傾向にあるので, 当面の生産規模を $70,000 \mathrm{t} /$ 月出鉣とし $\tau$, 今年下 10 番坑主要運搬坑道, 富士立坑下部集中貯鉱 舎および破砕設備等, 運搬の合理化工事ならびに富士総 合ポンプ施設による排水の合理化工事を完成するが，引 続きスラッシャの大型化, タイヤローダ, コンベヤロー ダ等探採機器増強計画の実施とともに, 前記懸案問題を 解決して,さらに生産性の向上と操業の安定を図りたい。

第 8 表 過去10年間の年間出鉣量, 平均品位 打よび能率（坑内, 全山）の推移

\begin{tabular}{|c|c|c|c|c|c|}
\hline & \multirow{2}{*}{ 年間出鉱量 $(\mathrm{t}$ ) } & \multicolumn{2}{|c|}{ 平均品位 $(\%)$} & \multicolumn{2}{|c|}{1 人 1 力月当り出鉱量 } \\
\hline & & $\mathrm{pb}$ & $\mathrm{Zn}$ & 坑内 $(t)$ & 全山( $t$ ) \\
\hline $\begin{array}{l}32 \text { 年 } \\
33 \\
34 \\
35 \\
36 \\
37 \\
38 \\
39 \\
40 \\
41 \\
\text { 棓均 }\end{array}$ & $\begin{array}{r}260,372 \\
268,465 \\
281,117 \\
309,777 \\
346,477 \\
408,266 \\
486,159 \\
521,334 \\
606,492 \\
689,966 \\
4,178,425 \\
417,843\end{array}$ & $\begin{array}{l}1.66 \\
1.67 \\
1.65 \\
1.46 \\
1.52 \\
1.53 \\
1.40 \\
1.23 \\
1.34 \\
1.33 \\
1.44\end{array}$ & $\begin{array}{l}4.39 \\
4.30 \\
4.25 \\
4.12 \\
4.02 \\
4.40 \\
4.05 \\
4.07 \\
3.95 \\
3.90 \\
4.10\end{array}$ & $\begin{array}{l}43.7 \\
45.3 \\
47.1 \\
52.8 \\
56.3 \\
64.2 \\
75.5 \\
75.5 \\
79.5 \\
90.2 \\
64.4\end{array}$ & $\begin{array}{l}13.6 \\
14.6 \\
15.6 \\
17.6 \\
20.5 \\
25.8 \\
31.0 \\
33.3 \\
45.5 \\
51.5 \\
25.5\end{array}$ \\
\hline
\end{tabular}

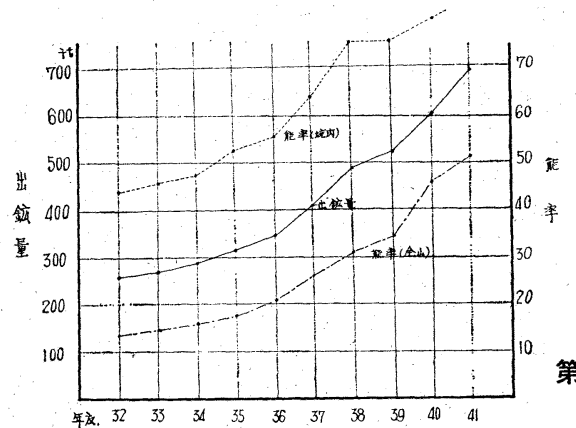

第 8 図
置し，上越線五日町駅または六日町駅より，東方それぞ れ $12 \mathrm{~km}$ および $15 \mathrm{~km}$ の地点にある。

\section{沿 革}

明治〜昭和．手掘りにて探鉱を行なつた旧坑を有 し，一部採掘跡がみられる。 